\title{
EVALUATION OF MAIZE WATER PRODUCTIVITY BY FAO- AQUACROP MODEL USING INTEGRATION OF MULCHING, NITROGEN FERTILIZATION AND IRRIGATION IN SALINE AND NON-SALINE SOILS
}

\author{
M. G. Zoghdan \\ Soils, Water and Environment Research Institute, 9 Cairo University Street, Giza, Egypt \\ Received: Jun. 29, 2021 \\ Accepted: Aug. 4, 2021
}

\begin{abstract}
The AquaCrop model (version 5) was validated using data from two field experiments carried out during the summer seasons of 2019 and 2020 in the North Delta (Sakha and El-Hamoul Districts). To research the impact of deficit irrigation, nitrogen fertilization and soil mulching on the productivity of maize water. Then, using such results, the AquaCrop model was validated by various statistical indicators such as determination coefficient $\left(R^{2}\right)$, normalized root means square error (NRMSE), degree of agreement $(D)$ and efficiency $(E)$. Results showed that under different irrigation regimes, nitrogen fertilization levels and mulching application in the North Delta, AquaCrop software was able to simulate well the crop water productivity (WP). Where R2, NRMSE, $D$ and $E$ were respectively0.88,0.36, 0.98 and 0.99 percent under non-saline soil conditions (Sakha location) values. While, under saline soil conditions, such values were $0.85,16.5,0.62$ and $0.87 \%$ for $R^{2}$, NRMSE, $D$ and E respectively. Data also, showed that, under non saline soil, the highest value of WP was obtained by irrigation at 40 days after post planting irrigation, then irrigation at $80 \%$ depletion from soil available water, nonlimiting nitrogen fertilization and using plastic mulching. While, under saline soil conditions, irrigation at 30 days after post planting irrigation, then irrigation at $60 \%$ depletion from soil available water, near optimal nitrogen fertilization and plastic mulching gave the best value of WP.
\end{abstract}

Key words: Aqua Crop, Model Validation, Deficit irrigation, Soil Salinity, Mulching.

\section{INTRODUCTION}

Due to the sharp decline in water supplies allocated to agriculture and the rapid population growth, there is an urgent need to increase crop water productivity (WP) (Kijne et al., 2003). This may involve in utilizing methods and practices that provide crops with a more specific supply of water. In addition, the effect of water constraints on crop production must be quantified. Therefore, the need to build crop simulation models was generated to use established knowledge of water supply yield responses and calculate yield losses.

In plant growth, yield and hence crop water productivity, nitrogen fertilization plays a key role. In maize production, this nutrient element is recognized as the first important nutrient that begins to restrict normal plant growth. More analysis and attention should be paid to nitrogen than any other nutrient. Mulch is usually applied at the start of the growing season, and is sometimes reapplied as needed. Initially, it helps to warm the soil and reduce heat loss at night. This enables early planting of cereal crops and promotes faster growth. As the season progresses, mulch maintain soil temperature and humidity and stops the germination of weed seeds by sunshine (Louise and James, 1996). Maize is one of the most commonly consumed cereal crops cultivated under various environmental conditions worldwide. In 
the next few decades, the rising global population will require increase on cereal cropss production to feed this population, which is governed by the amount of water available for irrigation. In addition, humanity must cope with climate change and the availability of water, especially in arid and semi-arid regions. Therefore, irrigated farming is under high pressure to improve crop water productivity. Several strategies and models were introduced to simulate current and future scenarios for water resource planning and management. AquaCrop is one of the most important models that reliably schedule irrigation and simulate achievable yields of major crops, with comparatively less data demand (Steduto et al., 2009).

Maize was the first crop selected to parametrize and test the new FAO AquaCrop model (Hsiao et al., 2009). Also, the model was used for growth simulation of cotton (Farahani et al., 2009), sunflower (Steduto et al., 2009), barley (Araya et al., 2010), and Teff (Eragrostis tef), under different water regimes. The results of these experiments revealed that the AquaCrop model can be used to explore management options and improve water quality. AquaCrop has been developed to provide an easy-to-use modeling method for a wide range of users interested in achievable crop biomass and harvestable yield under various water and nutrient input scenarios (farmers, agricultural consultants, water managers and policymakers) (Steduto et al., 2009). As the most limiting factor for crop growth, the model focuses on water input, especially in arid and semi-arid regions where water stress varies in intensity, duration and time of occurrence (K.J. and T.C., 1982). AquaCrop has a simple, user-friendly structure and uses 33 parameters of crop input that can be easily observed in the field, such as the percentage of canopy cover instead of the leaf area index (LAI) and other physiological inputs related to biomass; numerical and/or descriptive characterization of tolerance to crop water stress, soil texture and nutrient input. In fact, this simple structure and decreased number of parameters are expected to facilitate model calibration and utilization for various crops and under various management strategies. The model retains a significant number of key output data, including the simulation of canopy cover, biomass and soil water components over the entire growing cycle and the final harvestable yield, given the reduction and simplification of the input variables (Raes et al., 2009; Steduto et al., 2009). The aim of this research is to optimize crop water productivity under different treatments of deficit irrigation, soil mulching, nitrogen fertilization and soil salinity.

\section{MATERIALS AND METHODS}

\subsection{Sites and climate of the experimental field:}

The experiments were conducted on 2019 and 2020 at two experimental fields of North Delta (Egypt), Kafr El- Sheikh Governorate (Sakha and El-Hamoul). The first experimental field was located in Sakha (non-saline soil), 31.1 latitude, and 30.9 longitude. While, the second experimental field was conducted in ElHamoul District represent saline soil, $\mathbf{3 1 . 2}$ $\mathrm{N}$ and $31.8 \mathrm{E}$. Soil texture was clay in both fields of experiment. Values of field capacity were $41.8 \%$ and $41.5 \%$ for both non saline and saline soil respectively. Also, permanent wilting point percentages were 21.3 and $21.2 \%$ for non-saline and saline soil respectively. The area is characterized by a typical Mediterranean climate, with a hot and dry summer season. Weather data, including daily values of air temperature and humidity, wind speed and sunshine were collected at the agro meteorological 
station of Sakha agriculture research station, located about $50 \mathrm{~m}$ from Sakha location and $3 \mathrm{~km}$ from El-Hamoul location. Data in (Table 1) show the climatic data in such locations during the summer seasons of 2019 and 2020.

Some properties of the studied soils before cultivation are shown in Table. 2.

Table 1: Main values of meteorological data during maize growing seasons 2019 and 2020.

\begin{tabular}{|c|c|c|c|c|}
\hline Months & $\begin{array}{c}\text { Mean } \\
\text { temperature, } \mathbf{C}^{\mathbf{0}}\end{array}$ & $\begin{array}{c}\text { Relative humidity, } \\
\%\end{array}$ & $\begin{array}{c}\text { Wind speed, km } \\
\text { day }^{-1}\end{array}$ & $\begin{array}{c}\text { Sunshine, } \\
\text { hours }^{-}\end{array}$ \\
\hline May & 27.0 & 64.4 & 252.0 & 11.6 \\
\hline June & 30.8 & 71.7 & 217.4 & 13.1 \\
\hline July & 30.6 & 74.7 & 189.0 & 12.9 \\
\hline August & 29.4 & 73.1 & 178.5 & 12.1 \\
\hline September & 27.1 & 69.6 & 183.8 & 10.9 \\
\hline
\end{tabular}

Table 2: Some physical and chemical properties of the studied soils before cultivation

\begin{tabular}{|c|c|c|c|}
\hline \multicolumn{2}{|r|}{ Soil properties } & Normal soil & Saline soil \\
\hline \multirow{8}{*}{ 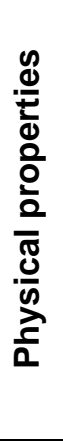 } & Sand \% & 17.1 & 16.7 \\
\hline & Silt \% & 26.8 & 23.9 \\
\hline & Clay \% & 57.1 & 60.4 \\
\hline & Soil texture & clay & clay \\
\hline & Field capacity,\% & 41.2 & 42.2 \\
\hline & Wilting point, \% & 20.5 & 21.4 \\
\hline & Bulk density, $\mathrm{Mg} \mathrm{m}^{-3}$ & 1.3 & 1.4 \\
\hline & Organic matter, \% & 1.9 & 1.6 \\
\hline \multirow{14}{*}{ 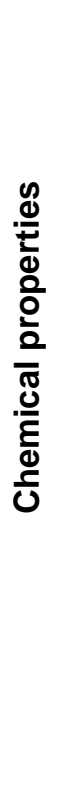 } & $\mathrm{CaCO} 3, \%$ & 2.5 & 4.4 \\
\hline & $\mathrm{pH}^{*}$ & 7.7 & 8.1 \\
\hline & $E C{ }^{* *}, \mathrm{dS} \mathrm{m}^{-1}$ & 1.9 & 5.7 \\
\hline & $\mathrm{Ca}^{++}$meq I$^{-1}$ & 3.8 & 13.1 \\
\hline & $\mathrm{Mg}^{++} \mathrm{meq} \mathrm{I}^{-1}$ & 2.1 & 12.4 \\
\hline & $\mathrm{Na}^{+}$meq I-1 & 12.9 & 30.4 \\
\hline & $\mathrm{K}^{+}$meq I-1 & 0.2 & 0.6 \\
\hline & $\mathrm{CO}^{--} \mathrm{meq} \mathrm{I}^{-1}$ & 0.0 & 0.0 \\
\hline & $\mathrm{HCO}_{3}^{-}$meq I-1 & 5.5 & 4.0 \\
\hline & $\mathrm{CL}^{-}$meq I-1 & 9.0 & 22.9 \\
\hline & SO4-- $^{- \text {meq I}^{-1}}$ & 4.5 & 29.6 \\
\hline & Available Nitrogen, mgkg $^{-1}$ & 51.1 & 30.4 \\
\hline & Available phosphorus. mgkg $^{-1}$ & 16.5 & 10.1 \\
\hline & Available potassium, $\mathrm{mgkg}^{-1}$ & 494.4 & 656.5 \\
\hline
\end{tabular}

${ }^{*} p H$ was determined in soil: water suspension (1:2.5).

${ }^{* *}$ EC was determined in soil paste extract. 


\subsection{Cultural practices and basic treatments:}

Maize (Zea Mays, L.) cross single 10 variety was planted with cropping density 5.0 plants per $\mathrm{m}^{2}$ in May 2019 and 2020 and harvested around September for both field experiments. Weeds were controlled by integrated weed management strategies that were standard of the region. The experiments, set according to a randomized block design with three replicates, including the following treatments: (1): Withholding in irrigation intervals after post planting irrigation by (20,30 and 40 days), only for the first irrigate after post planting irrigation., (2): Irrigation at different levels of depletion from soil available water by D1 (40 \%), D2 (60\%) and D3 (80\%) through all over the season after previous withholding intervals., (3): Four levels of nitrogen fertilization N1 (nonlimiting), N2 (near optimal), N3 (moderate), and N4 (poor)., (4): Two types of soil mulching i.e (plastic mulching and organic mulching).

\subsection{Description of AquaCrop model:}

AquaCrop is a new water-driven crop growth model (Raes et al., 2009; Steduto et al., 2009). The biomass growth rate is linearly proportional to transpiration through the following equation: $A G B=$ $W P \times T_{c} / E T$ 。

Where $A G B$ is the aboveground biomass rate; WP is the water productivity (biomass per unit of accumulated water transpired); $T_{c}$ is the crop transpiration; and ET。 is the reference evapotranspiration, used to normalize $T_{c}$.

Including infiltration, runoff, deep percolation, crop absorption, evaporation, transpiration, and capillary rise processes, soil water balance is carried out daily. The model keeps track of rainfall and irrigation and distinguishes evaporation through the percentage of canopy cover from transpiration as described in detail by (Raes et al., 2009; Steduto et al., 2009) . AquaCrop does not calculate ETo, and it is one of the weather inputs in the model. In this study, ET。 data were estimated from the nearby meteorological station using the FAO Penman-Monteith approach.

Via its soil and its water balance, the environment (rainfall, temperature, evapotranspiration, and concentration of carbon dioxide) and crop conditions (phenology, crop cover, root depth, development of biomass and harvestable yield) and field management (irrigation, fertility and field agronomic practices) components, AquaCrop relates its soilcrop-atmosphere components (Raes et al., 2009; Steduto et al., 2009).

\subsection{Methods of model validation and evaluation:}

The validation of the model was based on a comparison of simulated (foreseen) and observed (measured) data for all treatments. In particular, the following crop growth parameters were analyzed: (I): maize grain yield, and (II): maize water productivity. For such aim, several statistical indicators are available to evaluate the performance of a model (Loague and Green, 1991). Each has its own strengths and weaknesses, which means that it is important to use an ensemble of different metrics to evaluate the model's success adequately (Willmott, 1982) and (Legates and McCabe Jr, 1999). In the equations, the measurements and projections and their averages and the number of observations is $\mathrm{Oi}$ and $\mathrm{Pi}$, respectively. Models validated using different statistical indicators as described in detail by (Ding et al., 2021). 


\section{RESULTS AND DISCUSSION}

\subsection{Maize yield predictions under non saline soil conditions}

The simulated final grain yield of various treatments is compared with the calculated values as a description of the outcome of the simulations. Data in (Fig. 1) show that, the highest value of maize grain yield $4700 \mathrm{~kg}$ acre $^{-1}$ was obtained by irrigation after 20 days from post planting irrigation, then irrigation at $\mathbf{4 0} \%$ depletion from soil available water through all over the season as well as adding non limiting level from nitrogen fertilizer and using plastic mulching. This can be due to more saved water and improved crop growth by rising doses of nitrogen under such treatments. Values of maize grain yield were decreased with increasing the period of irrigation withholding after post planting irrigation to $\mathbf{3 0}$ and $\mathbf{4 0}$ days under the same other treatments as indicated in (Figs. 2 and 3 ). Respecting to AquaCrop validation with maize grain yield, data in (Table 3) showed that, there are an excellent agreement between measured and predicted values. Where, values of $\mathbf{R}^{2}$, NRMSE, EF and $D$ were $0.88,0.93,0.95$ and 0.97 respectively. Which mean that there are an excellent agreement between measured and predicted values of maize grain yield according to (Jacovides and Kontoyiannis, 1995; N. Moriasi et al., 2007).

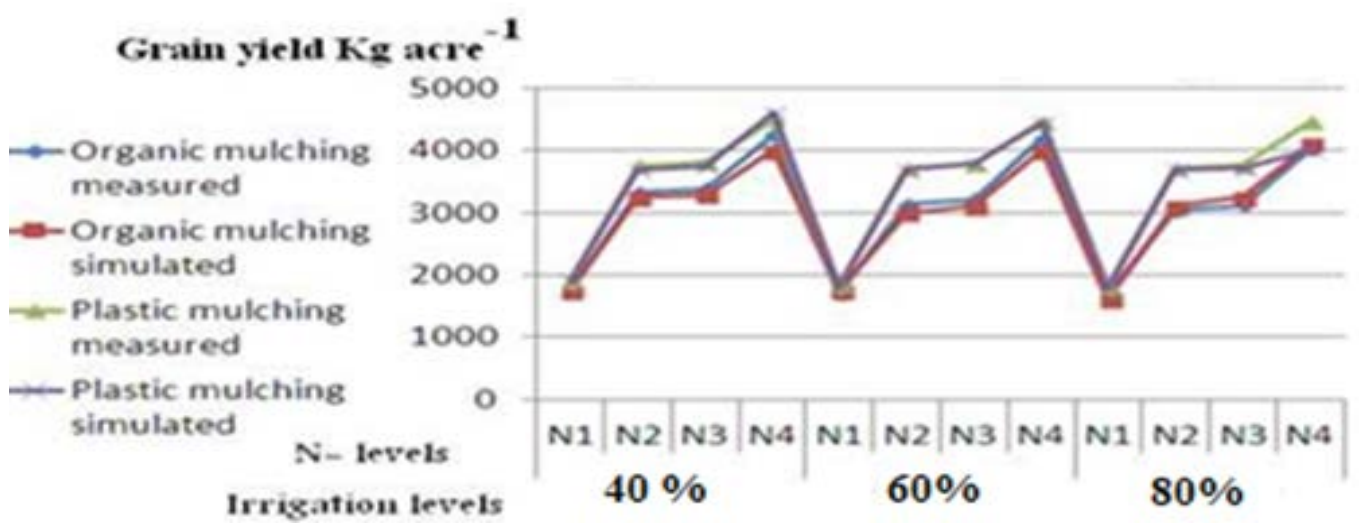

Fig.1: Simulated and measured values of maize grain yield as affected by different treatments under non saline soil conditions and irrigation after 20 days from post planting irrigation.

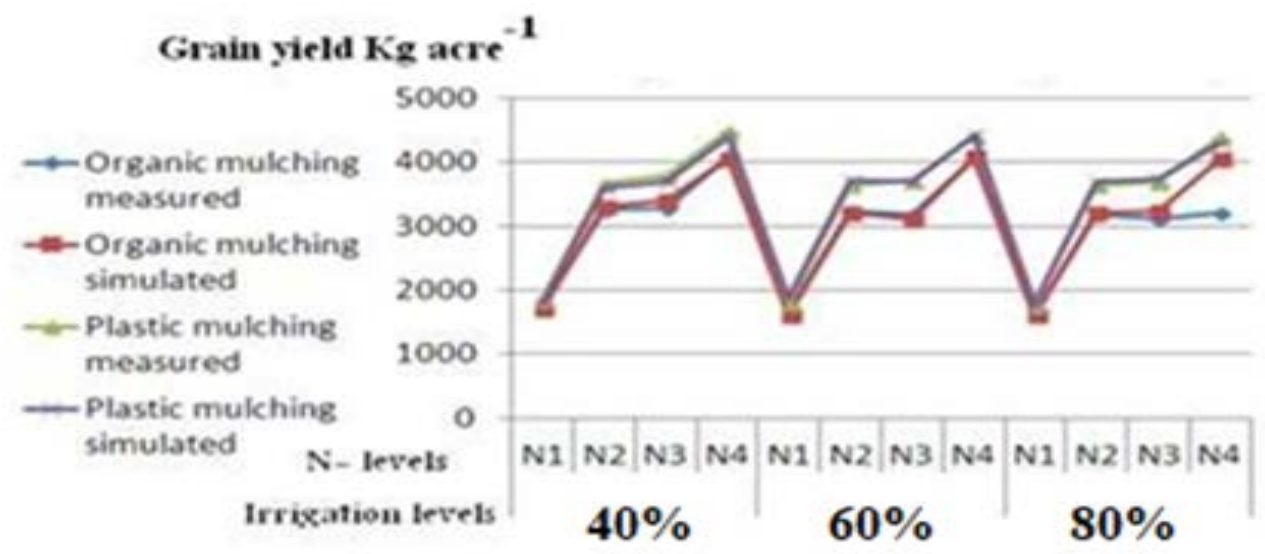

Fig. 2: Simulated and measured values of maize grain yield as affected by different treatments under non saline soil conditions and irrigation after $\mathbf{3 0}$ days from post planting irrigation 
M. G. Zoghdan, et al.,

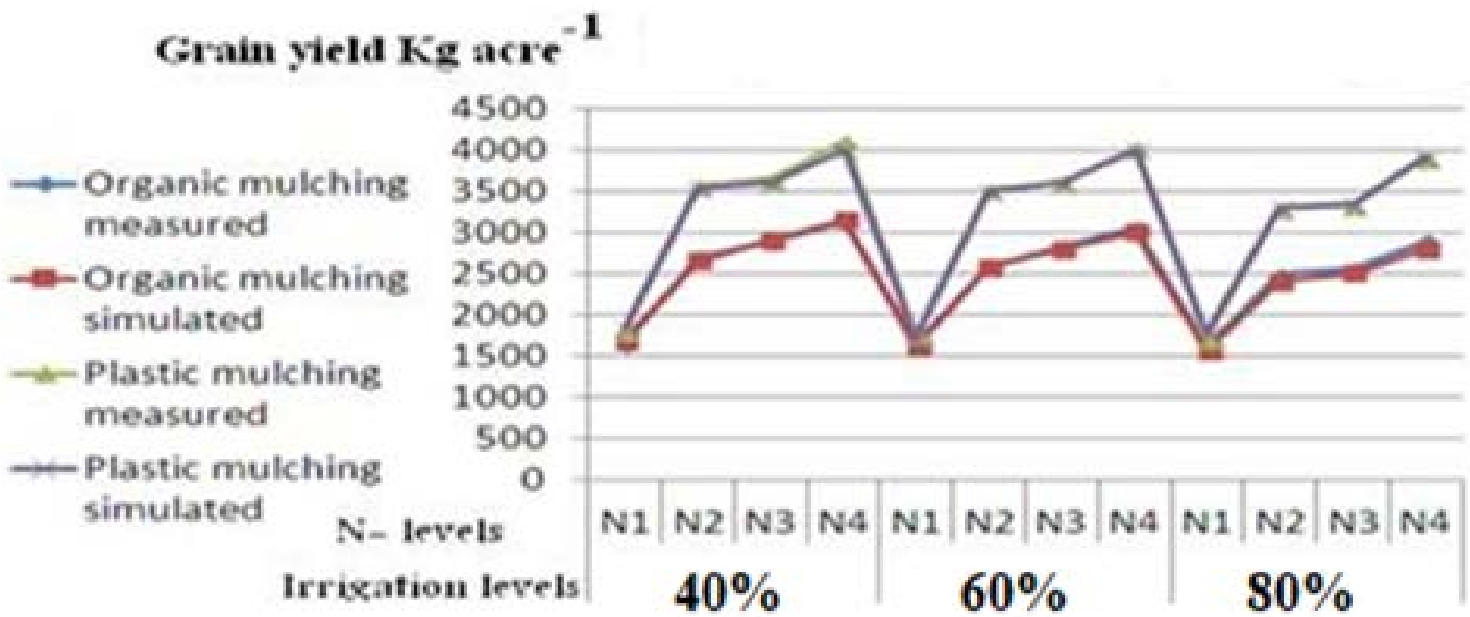

Fig. 3: Simulated and measured values of maize grain yield as affected by different treatments under non saline soil conditions and irrigation after $\mathbf{4 0}$ days from post planting irrigation.

Table 3: Evaluating AquaCrop model with maize grain yield under different treatments in non-saline soil conditions

\begin{tabular}{|c|c|c|c|c|}
\hline \multirow{6}{*}{$\begin{array}{l}\text { Statistical } \\
\text { indicators }\end{array}$} & \multicolumn{4}{|c|}{ Treatments } \\
\hline & $\begin{array}{l}\text { Elapsed time after } \\
\text { post planting } \\
\text { irrigation }\end{array}$ & $\begin{array}{l}\text { Irrigation at different } \\
\text { levels of depletion from } \\
\text { soil available water }\end{array}$ & $\begin{array}{l}\text { Nitrogen } \\
\text { fertilization } \\
\text { levels }\end{array}$ & $\begin{array}{c}\text { Soil } \\
\text { mulching }\end{array}$ \\
\hline & 20 days & $40 \%$ & Non limiting & Plastic \\
\hline & 30 days & $60 \%$ & Near optimal & Organic \\
\hline & 40 days & $80 \%$ & Moderate & \\
\hline & & & Poor & \\
\hline $\mathrm{R}^{2}$ & \multicolumn{4}{|c|}{0.88} \\
\hline NRMSE & \multicolumn{4}{|c|}{0.93} \\
\hline $\mathrm{EF}$ & \multicolumn{4}{|c|}{0.95} \\
\hline D & \multicolumn{4}{|c|}{0.97} \\
\hline
\end{tabular}

\subsection{Maize water productivity prediction under non saline soil conditions}

As shown in (Figs 4,5 and 6), values of WP were increased with using plastic mulching, level of non-limiting nitrogen fertilizer, and application of deficit irrigation. Where, the highest predicted value of WP $2.15 \mathrm{~kg} \mathrm{~m}^{-3}$ was obtained by irrigation after $\mathbf{4 0}$ days from post planting irrigation then irrigation at $80 \%$ depletion from soil available water, as well as adding level of non-limiting nitrogen fertilizer and using plastic mulching as compared to other treatments. Such increase in WP may be due to the following reasons:

1. Water loss through evaporation is reduced due to using plastic mulching.

2. The negative effect of drought stress during specific phonological stages on biomass partitioning between reproductive and vegetative biomass and harvest index (Fereres and 
Soriano, 2007; Hsiao et al., 2007; Reynolds and Tuberosa, 2008) is avoided, which stabilizes or increases the number of reproductive organs and/or the individual mass or reproductive organs (filling) (Karam et al., 2009).

3. WP for the net assimilation of biomass as follow:

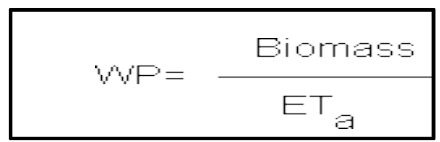

With biomass in the numerator and with $\mathrm{ET}_{\mathrm{a}}$ in the denominator is increased as drought stress is mitigated, or crops become more hardened. This effect is thought to be rather limited given the conservative behavior or biomass growth in response to transpiration (Steduto et al., 2007).

4. WP for the net assimilation of biomass is increased due to the synergy between irrigation and fertilization (Steduto and Albrizio, 2005). This includes cases where irrigation is reduced if fertilizer levels and native fertility are low (Geerts et al., 2008).

5. Negative agronomic conditions are avoided during crop growth, such as pests, diseases, anaerobic conditions in the root zone due to water logging, etc. (Pereira et al., 2002).

Data in (Table 4) showed an excellent agreement between measured and predicted values of WP under different treatments. Where, $R^{2}$ value was 0.88 which achieve a good agreement according to (Jacovides and Kontoyiannis, 1995; N. Moriasi et al., 2007).

The NRMSE value was less than $10 \%$, values of EF and D were 0.88 and 0.79 respectively. Therefore, AquaCrop model was able to simulate maize water productivity under non saline soil conditions.

\section{WP Kg m $\mathrm{m}^{-3}$}

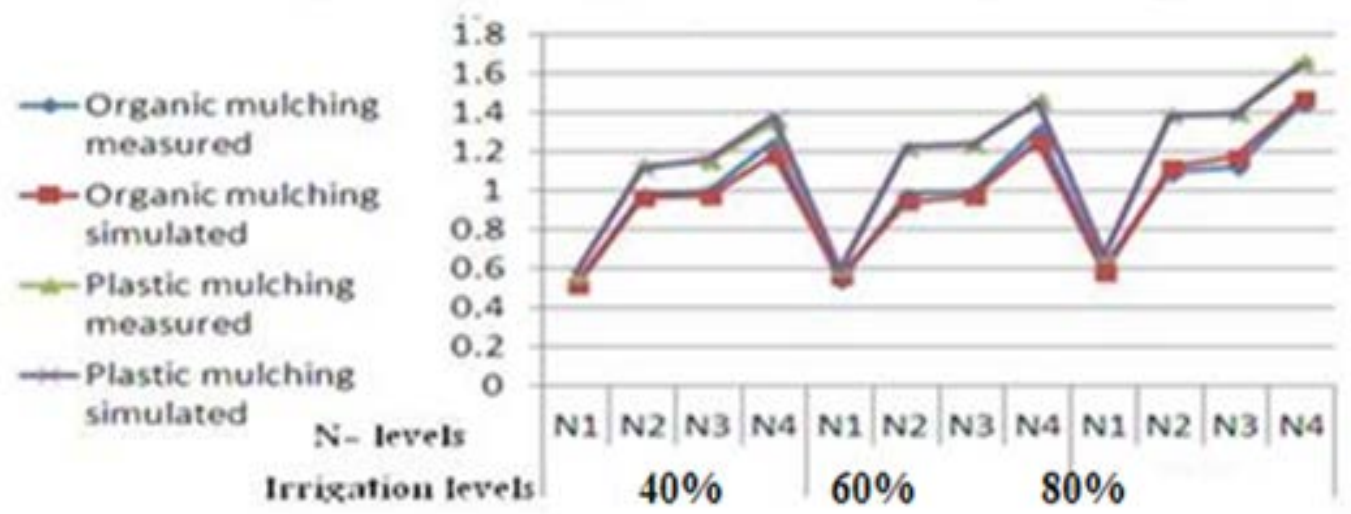

Fig. 4: Simulated and measured values of maize water productivity as affected by different treatments under non saline soil conditions and irrigation after 20 days from post planting irrigation 
M. G. Zoghdan, et al.,

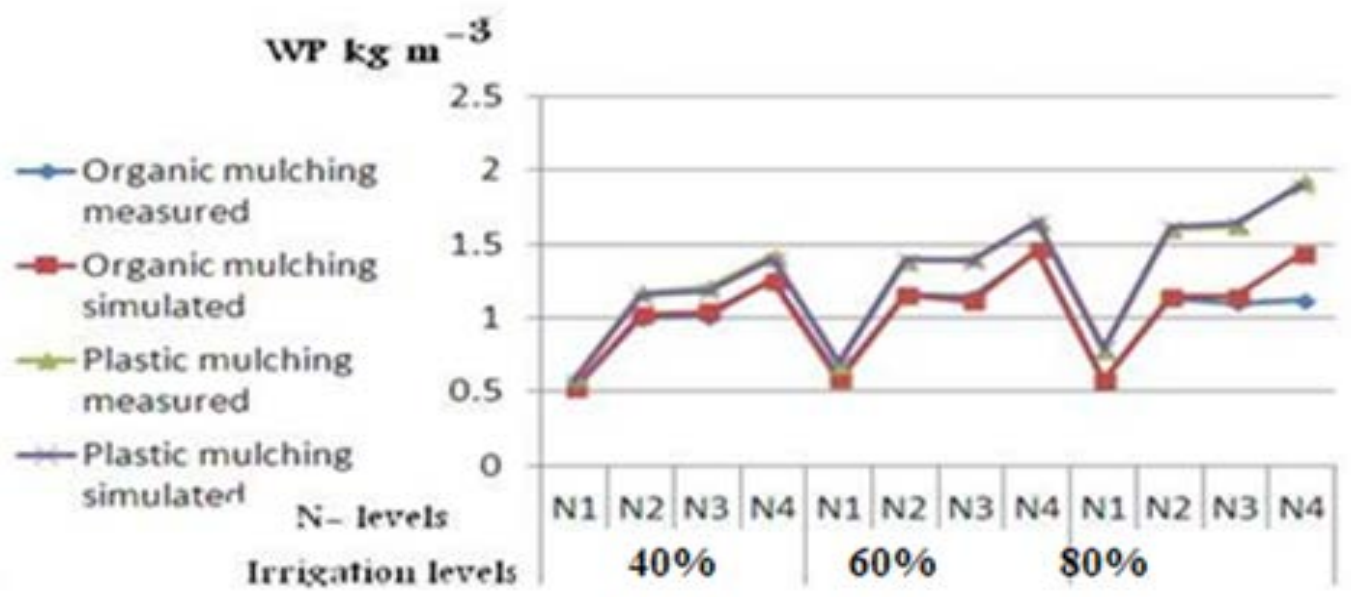

Fig. 5: Simulated and measured values of maize water productivity as affected by different treatments under non saline soil conditions and irrigation after $\mathbf{3 0}$ days from post planting irrigation.

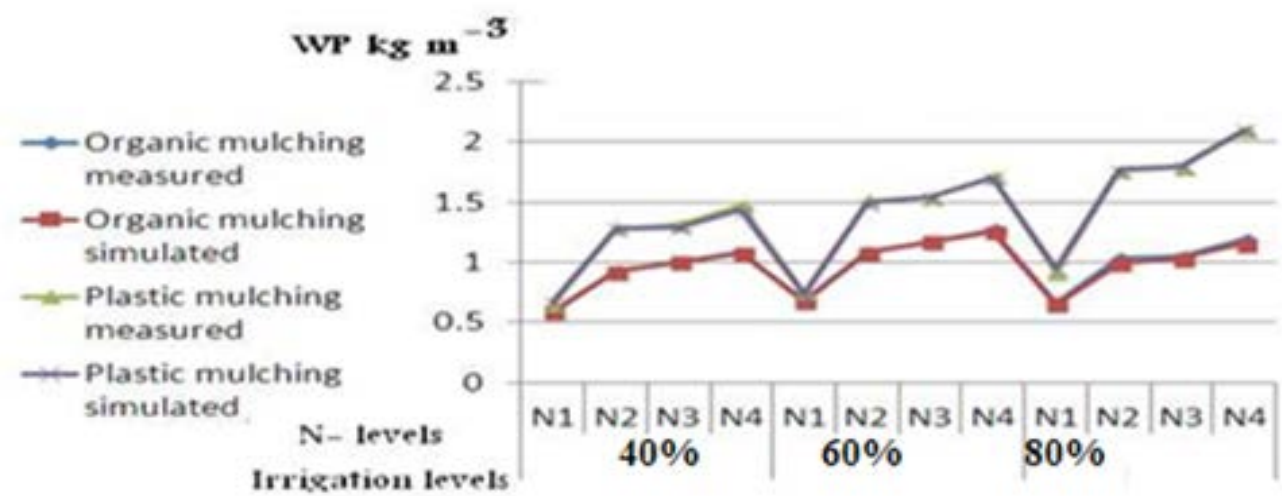

Fig. 6: Simulated and measured values of maize water productivity as affected by different treatments under non saline soil conditions and irrigation after $\mathbf{4 0}$ days from post planting irrigation.

Table 4: Evaluating AquaCrop model using maize water productivity under different treatments of non-saline soil conditions

\begin{tabular}{|c|c|c|c|c|}
\hline \multirow{6}{*}{$\begin{array}{l}\text { Statistical } \\
\text { indicators }\end{array}$} & \multicolumn{4}{|c|}{ Treatments } \\
\hline & $\begin{array}{c}\text { Elapsed time after } \\
\text { post } \\
\text { planting irrigation }\end{array}$ & $\begin{array}{c}\text { Irrigation at different } \\
\text { levels of } \\
\text { depletion from soil } \\
\text { available water }\end{array}$ & $\begin{array}{l}\text { Nitrogen } \\
\text { fertilization } \\
\text { levels }\end{array}$ & $\begin{array}{c}\text { Soil } \\
\text { mulching }\end{array}$ \\
\hline & 20 days & $40 \%$ & Non limiting & Plastic \\
\hline & 30 days & $60 \%$ & Near optimal & Organic \\
\hline & 40 days & $80 \%$ & Moderate & \\
\hline & & & Poor & \\
\hline $\mathbf{R}^{2}$ & \multicolumn{4}{|c|}{0.88} \\
\hline NRMSE & \multicolumn{4}{|c|}{0.36} \\
\hline EF & \multicolumn{4}{|c|}{0.88} \\
\hline D & \multicolumn{4}{|c|}{0.79} \\
\hline
\end{tabular}




\subsection{Prediction of maize grain yield under saline soil conditions}

AquaCrop model (version 5) uses the calculation procedure presented in Budget (De Nys et al., 2005) to simulate salt movement and retention in the soil profile. The highest predicted value of maize grain yield under salinity conditions $1750 \mathrm{~kg}$ acre ${ }^{-1}$ was obtained by irrigation after 20 days from post planting irrigation followed by irrigation at $40 \%$ depletion from soil available water as well as using plastic mulching and level of non-limiting from nitrogen fertilizer, as shown in (Fig. 7). Values of maize grain yield were decreased with increasing the period of irrigation intervals after post planting irrigation as indicated in (Figs. 8 and 9).

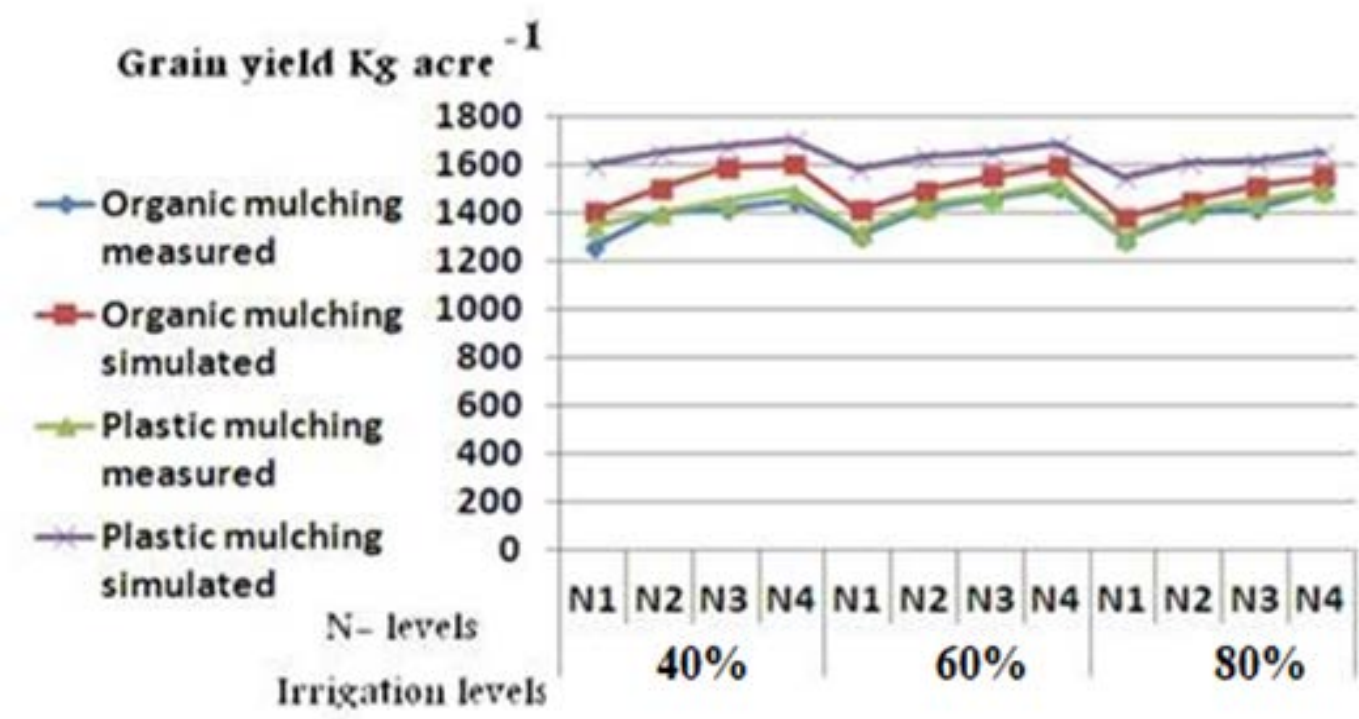

Fig. 7: Simulated and measured values of maize grain yield as affected by different treatments under saline soil conditions and irrigation after 20 days from post planting irrigation.

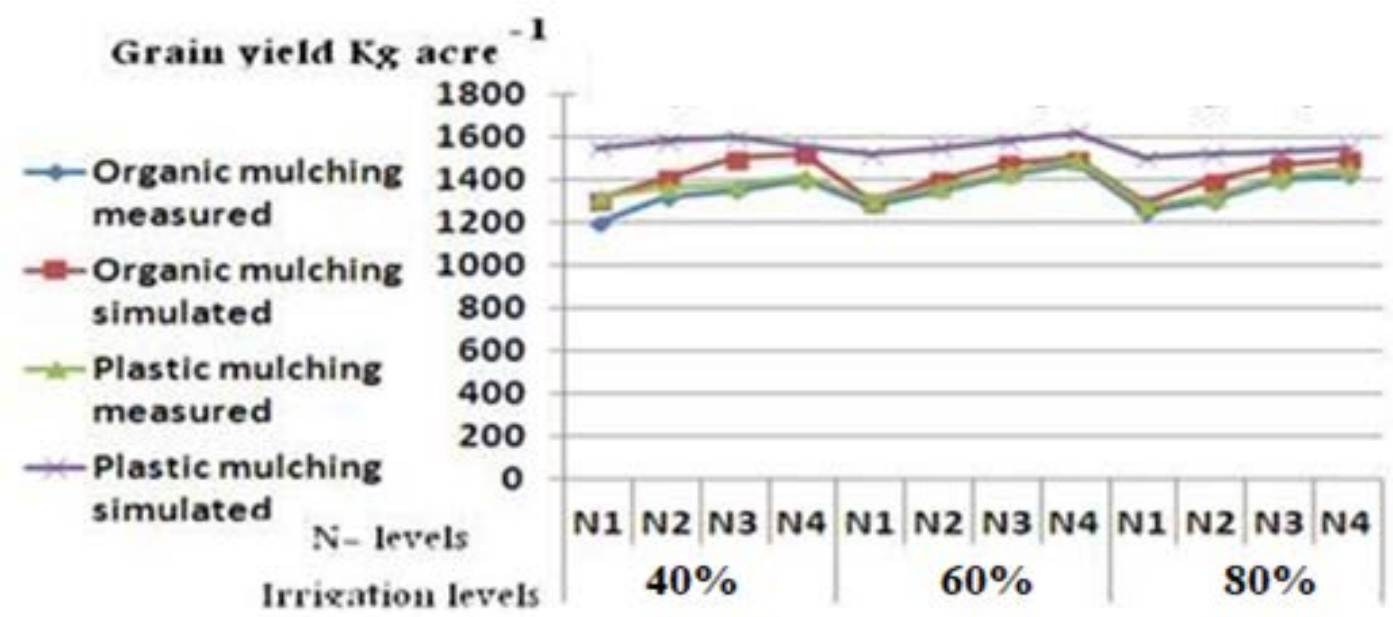

Fig. 8: Simulated and measured values of maize grain yield as affected by different treatments under saline soil conditions and irrigation after 30 days from post planting irrigation 
M. G. Zoghdan, et al.,

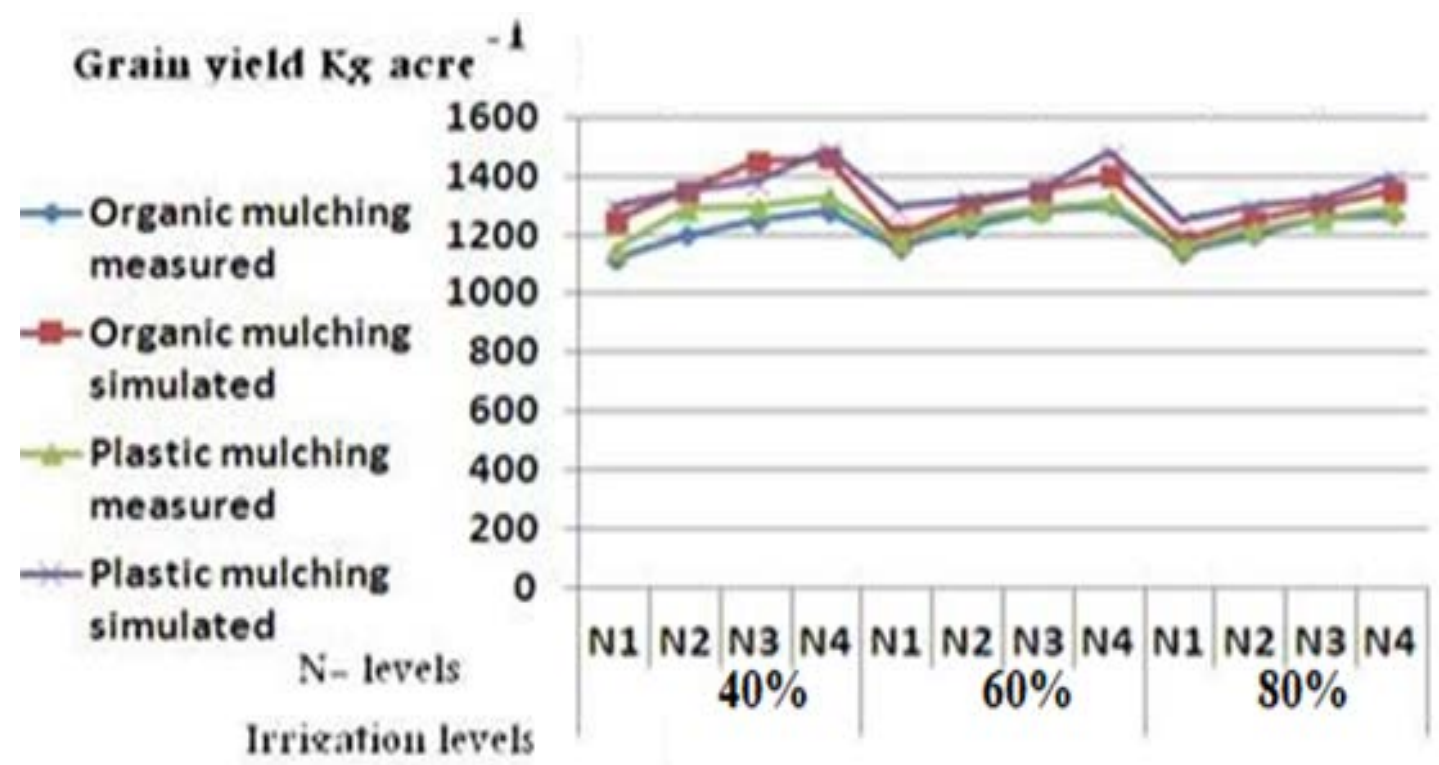

Fig. 9: Simulated and measured values of maize grain yield as affected by different treatments under saline soil conditions and irrigation after $\mathbf{4 0}$ days from post planting irrigation

As mentioned in (Table 5) values of statistical indicators were $0.88,16.5,0.73$ and 0.85 for $R^{2}$, NRMSE, EF and $D$ respectively. Such values indicate a good an agreement between measured and predicted values of grain yield.

\subsection{Prediction of maize water productivity under saline soil conditions}

Values of WP were increased due to increasing nitrogen fertilization, irrigation after 30 days from post planting irrigation followed by $60 \%$ depletion from available water and using plastic mulching as shown in (Figs.10,11 and 12). Where, the highest value of WP $0.78 \mathrm{~kg} \mathrm{~m}^{-3}$ was obtained by irrigation after $\mathbf{3 0}$ days from post planting irrigation followed by irrigation at $60 \%$ depletion from soil available water in addition to using plastic mulching and adding level of nonlimiting from nitrogen fertilizer. This may be attributed to the clay texture and shallow level of ground water table which might contribute in crop water consumptive use (Fidantemiz et al., 2019). The highest values of WP were achieved in case of plastic mulching, irrigation after $\mathbf{3 0}$ days from post planting irrigation and resume depletion by $60 \%$ from available water (Fig. 11), may be attributed to deceasing evaporation, and improved crop productivity. Respecting to AquaCrop evaluation under this condition. Data presented in (Table 6) report that, there are a good agreement between measured and predicted values of WP. Where, values of $R^{2}$, NRMSE, EF and $D$ were $0.78,18.5,0.52$ and 0.77 respectively. Therefore, AquaCrop model could be used adequately under these conditions to predict crop water productivity with different treatments like irrigation, fertilization and field practice management. 
Table 5: Evaluating AquaCrop model with maize grain yield under different treatments in saline soil conditions

\begin{tabular}{|c|c|c|c|c|}
\hline \multirow{6}{*}{$\begin{array}{l}\text { Statistical } \\
\text { indicators }\end{array}$} & \multicolumn{4}{|c|}{ Treatments } \\
\hline & $\begin{array}{l}\text { Elapsed time } \\
\text { after } \\
\text { post planting } \\
\text { irrigation }\end{array}$ & $\begin{array}{c}\text { Irrigation at different } \\
\text { levels of } \\
\text { depletion from soil } \\
\text { available water }\end{array}$ & $\begin{array}{l}\text { Nitrogen } \\
\text { fertilization } \\
\text { levels }\end{array}$ & $\begin{array}{c}\text { Soil } \\
\text { mulching }\end{array}$ \\
\hline & 20 days & $40 \%$ & Non limiting & Plastic \\
\hline & 30 days & $60 \%$ & Near optimal & Organic \\
\hline & 40 days & $80 \%$ & Moderate & \\
\hline & & & Poor & \\
\hline $\mathbf{R}^{2}$ & \multicolumn{4}{|c|}{0.88} \\
\hline NRMSE & \multicolumn{4}{|c|}{16.5} \\
\hline EF & \multicolumn{4}{|c|}{0.73} \\
\hline D & \multicolumn{4}{|c|}{0.85} \\
\hline
\end{tabular}

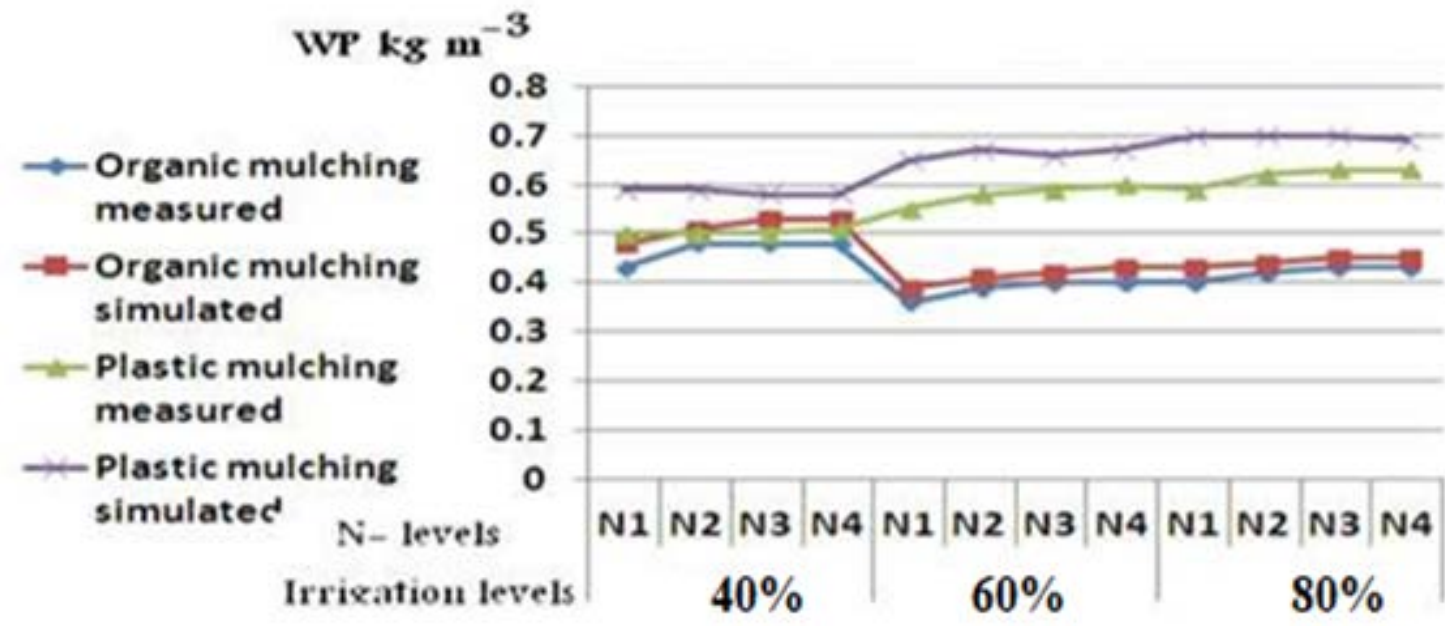

Fig. 10: Simulated and measured values of maize water productivity as affected by different treatments under saline soil conditions and irrigation after 20 days from post planting irrigation.

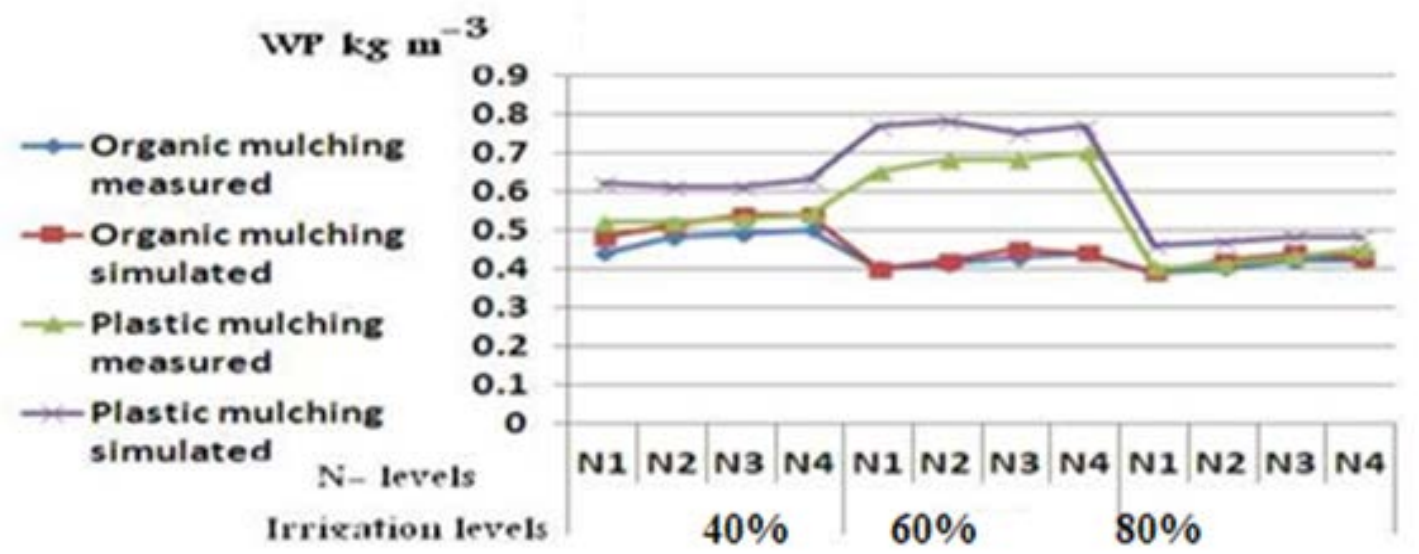

Fig. 11: Simulated and measured values of maize water productivity as affected by different treatments under saline soil conditions and irrigation after 30 days from post planting irrigation 


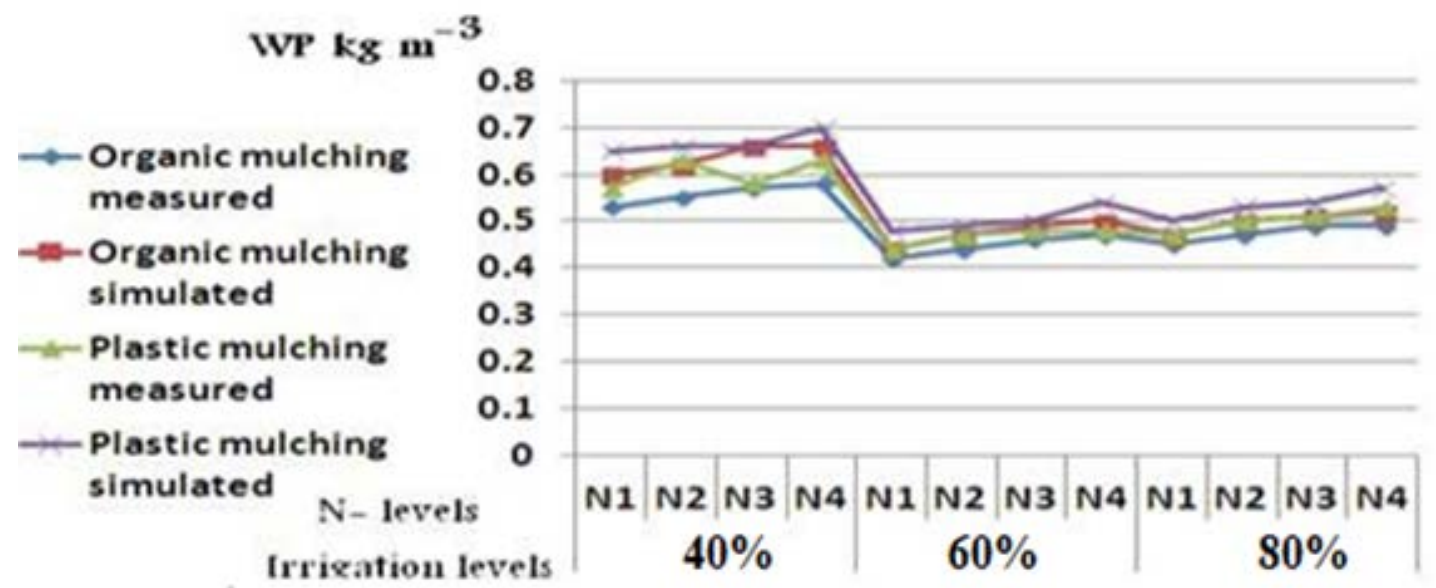

Fig. 12: Simulated and measured values of maize water productivity as affected by different treatments under saline soil conditions and irrigation after $\mathbf{4 0}$ days from post planting irrigation

Table 6: Evaluating AquaCrop model with maize water productivity under different treatments in saline soil conditions

\begin{tabular}{|c|c|c|c|c|}
\hline \multirow{6}{*}{$\begin{array}{l}\text { Statistical } \\
\text { indicators }\end{array}$} & \multicolumn{4}{|c|}{ Treatments } \\
\hline & $\begin{array}{l}\text { Elapsed time } \\
\text { after post } \\
\text { planting } \\
\text { irrigation }\end{array}$ & $\begin{array}{l}\text { Irrigation at different } \\
\text { levels of } \\
\text { depletion from soil } \\
\text { available water }\end{array}$ & $\begin{array}{l}\text { Nitrogen } \\
\text { fertilization } \\
\text { levels }\end{array}$ & $\begin{array}{c}\text { Soil } \\
\text { mulching }\end{array}$ \\
\hline & 20 days & $40 \%$ & Non limiting & Plastic \\
\hline & 30 days & $60 \%$ & Near optimal & Organic \\
\hline & 40 days & $80 \%$ & Moderate & \\
\hline & & & Poor & \\
\hline $\mathrm{R}^{2}$ & \multicolumn{4}{|c|}{0.78} \\
\hline NRMSE & \multicolumn{4}{|c|}{18.5} \\
\hline EF & \multicolumn{4}{|c|}{0.52} \\
\hline D & \multicolumn{4}{|c|}{0.77} \\
\hline
\end{tabular}

\section{CONCLUSION}

Under various treatments such as irrigation regimes, nitrogen fertilization, soil salinity and soil mulching in the North delta soils, AquaCrop software (version,5) successfully simulated grain yield and water productivity of maize crop. This model can also be used as a decision-making tool by project managers, consultants, irrigation engineers and farmers to improve water efficiency. Also, the highest value of maize water productivity was achieved by irrigation after 40 days post planting irrigation, then irrigation at $80 \%$ depletion from soil available water as well as applying both non limiting nitrogen fertilizer and plastic mulching, under non saline soil conditions. Though, under saline soil conditions, the highest value of crop water productivity was achieved by irrigation after $\mathbf{3 0}$ days from 
post-planting irrigation to 60 per cent depletion from soil usable water through season, in addition to the addition of moderate nitrogen fertilizer and plastic mulching.

\section{Acknowledgments}

This research has been undertaken with the support from Dr Ahmed Kheir. Research funded by Agriculture Research Center, Egypt and carried out in North Delta region (Kafr El-Sheikh Governorate), Egypt.

\section{REFERENCES}

Araya, A., Habtu, S., Hadgu, K. M., Kebede, A., and Dejene, T. (2010). Test of AquaCrop model in simulating biomass and yield of water deficient and irrigated barley (Hordeum vulgare). Agricultural Water Management 97, 1838-1846.

De Nys, E., D. Raes, P. Y. Le Gal, G. Cordeiro, S. Speelman and K. Vandersypen (2005). Predicting soil salinity under various strategies in irrigation systems. JOURNAL OF IRRIGATION AND DRAINAGE ENGINEERING-ASCE. 131, 351-357.

Ding, Z., E. F. Ali, A. M. Elmahdy, K .E. Ragab, M. F. Seleiman and A. M. S. Kheir (2021). Modeling the combined impacts of deficit irrigation, rising temperature and compost application on wheat yield and water productivity. Agricultural Water Management 244, 106626.

Farahani, H. J., G. Izzi and T. Y. Oweis (2009). Parameterization and Evaluation of the AquaCrop Model for Full and Deficit Irrigated Cotton. Agronomy Journal 101, 469-476.

Fereres, E. and M. A. Soriano (2007). Deficit irrigation for reducing agricultural water use. Journal of Experimental Botany 58, 147-159.

Fidantemiz, Y. F., X. Jia, A. L. M. Daigh, H.
Hatterman-Valenti, D. D. Steele, A. R. Niaghi and H. Simsek (2019). Effect of Water Table Depth on Soybean Water Use, Growth, and Yield Parameters. Water 11.

Geerts, S., D. Raes, M. Garcia, J. Vacher, R. Mamani, J. Mendoza, R. Huanca, B. Morales, R. Miranda, J. Cusicanqui and C. Taboada (2008). Introducing deficit irrigation to stabilize yields of quinoa (Chenopodium quinoa Willd.). European Journal of Agronomy 28, 427-436.

Hsiao, T. C., L. Heng, P. Steduto, B. Rojas-Lara, D. Raes and E. Fereres (2009). AquaCrop-The FAO Crop Model to Simulate Yield Response to Water: III. Parameterization and Testing for Maize. Agronomy Journal 101, 448-459.

Hsiao, T. C., P. Steduto and E. Fereres (2007). A systematic and quantitative approach to improve water use efficiency in agriculture. Irrigation Science 25, 209-231.

Jacovides, C. P. and H. Kontoyiannis (1995). Statistical procedures for the evaluation of evapotranspiration computing models. Agricultural Water Management 27, 365-371.

Bradford, K.J. and T.C. Hsiao (1982). Physiological Responses to Moderate Water Stress. In: Lange O.L., Nobel P.S., Osmond C.B., Ziegler H. (eds) Physiological Plant Ecology II.,Encyclopedia of Plant Physiology (New Series), 12.

Karam, F., Kabalan, R., Breidi, J., Rouphael, Y., and Oweis, T. (2009). Yield and water-production functions of two durum wheat cultivars grown under different irrigation and nitrogen regimes. Agricultural Water Management 96, 603-615.

Kijne, J. W., R. Barker and D. Molden (2003). Water Productivity in Agriculture: Limits and Opportunities 
M. G. Zoghdan, et al.,

for Improvement. Comprehensive Assessment of Water Management in Agriculture Series 1, International Water Management Institute, Srilanka.,

Legates, D. R. and G. J. McCabe Jr (1999). Evaluating the use of "goodness-of-fit" Measures in hydrologic and hydroclimatic model validation. Water Resources Research 35: 233-241.

Loague, K. and R. E. Green (1991). Statistical and graphical methods for evaluating solute transport models: Overview and application. Journal of Contaminant Hydrology 7, 51-73.

Louise, B. B. and B. P. James (1996). America's garden book,. New York, Macmillan USA, 768.

Moriasi,N., D. G. Arnold, J.W. Van Liew, M. L. Binger, R.D. Harmel and L.T. Veith (2007). Model Evaluation Guidelines for Systematic Quantification of Accuracy in Watershed Simulations. Transactions of the ASABE 50, 885-900.

Pereira, L. S., I. Cordery and I. Lacovides (2002). Coping with Water Scarcity. UNESCO IHP VI, Technical Documents in Hydrology 58.

Raes, D., P. Steduto, T. C. Hsiao and E. Fereres (2009). AquaCrop-The FAO
Crop Model to Simulate Yield Response to Water: II. Main Algorithms and Software Description . Agronomy Journal 101, 438-447.

Reynolds, M. and R. Tuberosa (2008). Translational research impacting on crop productivity in drought-prone environments. Curr Opin Plant Biol 11, 171-9.

Steduto, P. and R. Albrizio (2005). Resource use efficiency of field-grown sunflower, sorghum, wheat and chickpea: II. Water use efficiency and comparison with radiation use efficiency. Agricultural and Forest Meteorology 130, 269-281.

Steduto, P., T. C. Hsiao and E. Fereres (2007). On the conservative behavior of biomass water productivity. Irrigation Science 25, 189-207.

Steduto, P., T. C. Hsiao, D. Raes and E. Fereres (2009). AquaCrop-The FAO Crop Model to Simulate Yield Response to Water: I. Concepts and Underlying Principles. Agronomy Journal 101, 426-437.

Willmott, C. J. (1982). Some comments the evaluation of model performance. Bulletin American Meteorological Society 63, 1309-1313. 
تقييم انتاجيه وحده المياه من الذره باستخدام النموذج الرياضي اكواكروب من خلال

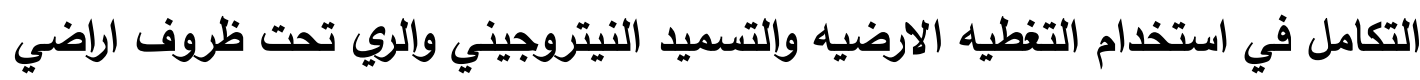

$$
\text { ملحيه وغير ملحيه }
$$

مدحت جابر طلحه زغدان

معهر بحوث الاراضي وإلمياه والبيئه ، مركز البحوث الزراعيه

الملخص العربى (الجربت

اجريت الاراسه بهاف التحقق من صحة نموذج AquaCrop (الإصدار الخامس) باستخدام بيانات من تجربتين

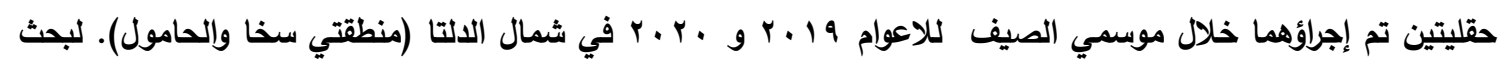

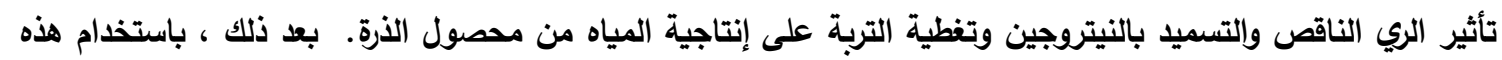

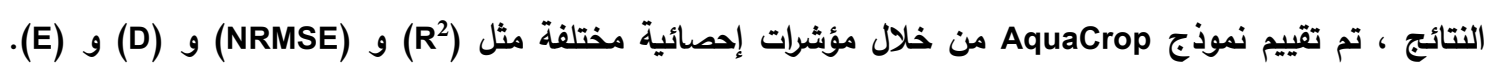

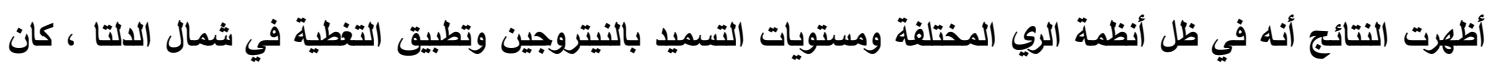

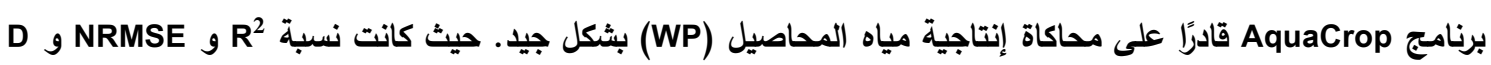

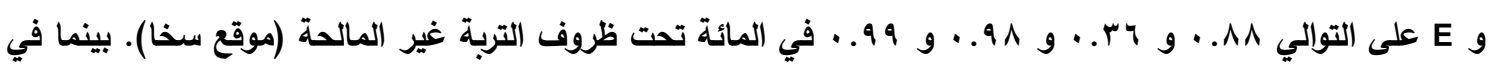

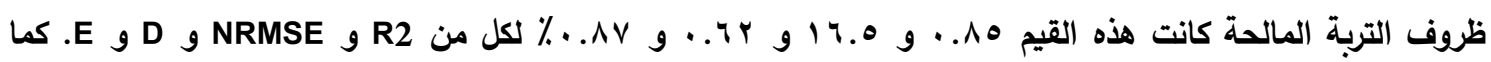

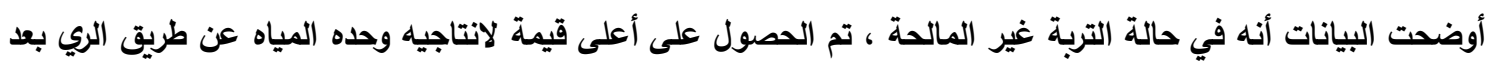

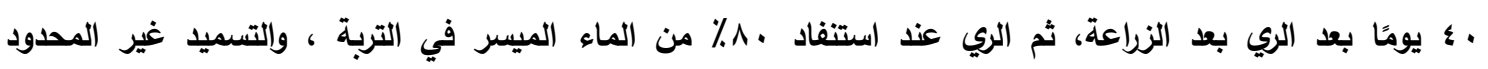

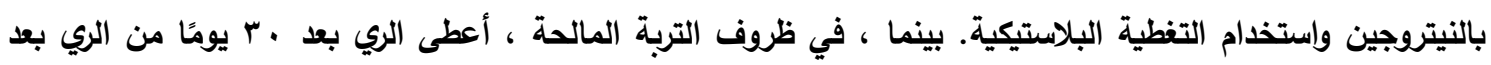

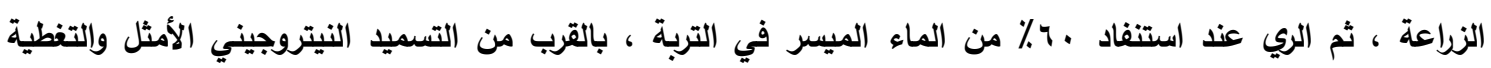

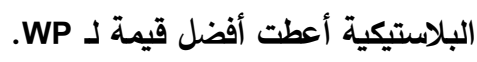

$$
\begin{aligned}
& \text { أسماء السادة المحكمين }
\end{aligned}
$$

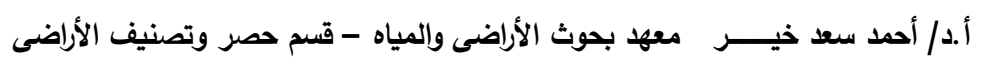

$$
\begin{aligned}
& \text { أ.د/ وائل السيد عمران كلية الزراعة - جامعة المنوفية }
\end{aligned}
$$

